\title{
VARIASI GENETIK HIBRIDA IKAN GURAME DIANALISIS DENGAN MENGGUNAKAN MARKER RAPD
}

\author{
Estu Nugroho", Sri Sundari*), dan Jatnika**) \\ *) Balai Riset Perikanan Budidaya Air Tawar \\ Jl. Sempur Raya No. 1, Bogor \\ E-mail:brpbat@yahoo.com \\ **) Fakultas Perikanan Universitas Padjajaran \\ Jl.Raya Bandung Sumedang Km. 21, Jatinangor 45363
}

(Naskah diterima: 21 Januari 2011; Disetujui publikasi: 11 April 2011)

\begin{abstract}
ABSTRAK
Variasi genetik ikan gurame hasil persilangan telah dianalisis dengan menggunakan marker RAPD. Persilangan antar koleksi yaitu Bastar-Paris, Bastar-Blusafir, dan ParisBlusafir dilakukan secara resiprok. DNA diekstraksi dari sirip dan diamplifikasi dengan menggunakan primer OPA 1-20. Dua dari dua puluh primer mempunyai hasil amplifikasi dan pola pita yang baik dan digunakan untuk analisis selanjutnya. Tidak terdapat perbedaan yang nyata secara statistik antar persilangan yang diuji. Benih ikan gurame hasil persilangan antara Paris-Bastar mempunyai nilai heterozygositas tertinggi berdasarkan primer OPA-4 dan OPA-7 yaitu 0.2721, sedangkan heterozygositas yang terendah diamati pada benih hasil persilangan antara Blusafir-Paris (0.1116).
\end{abstract}

KATA KUNCI: variasi genetik, ikan gurame, hibrida

ABSTRACT: Genetic variation of giant gouramy hybrids revealed by RAPD Marker. By: Estu Nugroho, Sri Sundari, and Jatnika

Genetic variations of giant gouramy hybrids was observed using RAPD Marker. Cross breeding among collections of Giant gouramy have been conducted recripocally i.e. Bastar-Paris, Bastar-Blusafir and Paris-Blusafir. Whole DNA was extracted from the fin clips and amplified using primer OPA 1-20. Two of 20 primers have good amplification result and band patterns and were used in further analysis. There was no statistically significant differences among tested fish. Giant gouramy from ParisBastar has the highest heterozygosity value based on the two primers (OPA-4 and OPA-7) i.e. 0.2721, while the lowest was observed in Blusafir-Paris (0.1116).

KEYWORDS: genetic variation, giant gouramy, hybrids

\section{PENDAHULUAN}

Gurame merupakan salah satu ikan ekonomis penting air tawar yang memiliki nilai jual tinggi. Selain dari nilai ekonomi yang menjanjikan, gurame memiliki sifat yang menguntungkan sebagai pemakan tanaman (herbivora) sehingga biaya pemeliharaannya relatif rendah. Kelebihan lain dari gurame adalah dapat hidup pada lingkungan perairan berkadar oksigen rendah dengan adanya alat pernapasan tambahan.

Namun demikian, berdasarkan observasi yang telah banyak dilakukan, pengembangan budidaya gurame terkendala oleh adanya permasalahan yang berkaitan lambatnya laju pertumbuhan pada ikan ini. Untuk mencapai 
ukuran konsumsi ikan gurame membutuhkan waktu yang lama sekitar 12-14 bulan. Meskipun teknik budidaya telah dikuasai sejak lama, perbaikan genetik yang berkaitan dengan upaya mempercepat laju pertumbuhan serta aplikasi teknologi yang tepat guna sangat diperlukan. Salah satu di antaranya adalah dengan memanfaatkan jenis-jenis ras yang ada.

Di Indonesia dikenal beberapa strain ikan gurame seperti Soang, Jepang, Paris, Bastar, dan Porselen yang telah banyak digunakan dalam kegiatan budidaya (Sudarto, 1989). Identifikasi strain gurame menggunakan analisis morfometrik dan biokimia telah dilakukan oleh peneliti-peneliti terdahulu (Soewardi et al., 1995; Soewardi, 1995; Kusmini et al., 2000; Suseno et al., 2000). Analisis tiga strain ikan gurame dengan truss morfometrik dilakukan oleh Setijaningsih et al. (2007).

Menurut Nugroho et al. (1993), terdapat perbedaan morfologi dan potensi pertumbuhan beberapa strain ikan gurame. Selanjutnya Nugroho \& Kusmini (2007) mengemukakan bahwa pada pengujian variasi genetik strain Bastar, Bule, dan Blue Safir yang dikoleksi dari daerah Parung, Jawa Barat dengan isozyme menunjukkan tidak terdapat perbedaan yang nyata di antara ketiga strain tersebut. Nilai heterosigositas berkisar antara 0,125-0,137 dengan jarak genetik rata-rata antar strain sebesar 0,0003.

Pemanfaatan ras-ras ikan gurame dapat dilakukan melalui jalan hibridisasi. Hibridisasi bertujuan untuk memunculkan karakterkarakter tetua yang berbeda secara genetis pada turunan berikutnya sebagai efek heterosis atau sifat unggul (Falconer, 1996). Tave (1993) menerangkan bahwa eksploitasi variasi dominan dapat dilakukan untuk memperbaiki produktivitas ikan melalui hibridisasi. Pengetahuan tentang karakter-karakter unggul induknya yang diturunkan ke generasi berikutnya dapat diobservasi dengan menggunakan marker DNA. Salah satu marker DNA yang mempunyai kemampuan untuk menganalisa variasi DNA adalah Random Amplified Polymorphism DNA (RAPD).

Penelitian ini bertujuan untuk mengkarakterisasi secara DNA variasi genetik antara hibrida-hibrida ikan gurame dalam rangka mendapatkan peta genetik yang dapat dimanfaatkan dalam memproduksi ras unggul ikan gurame.

\section{BAHAN DAN METODE}

\section{Ikan Uji}

Ikan uji yang digunakan dalam penelitian ini adalah ikan gurame yang berasal dari daerah Parung-Bogor. Adapun ras-ras ikan gurame yang digunakan adalah Soang/Bastar (A), Paris (B), dan Blusafir (C). Sedangkan hibrida-hibrida yang digunakan adalah hasil silangan secara resripok antara ketiga jenis ras tersebut, yaitu $A B, B A, A C, C A, B C$, dan CB. Jumlah sampel yang digunakan untuk masing-masing persilangan adalah 10 ekor.

\section{Ekstraksi DNA}

DNA ikan diekstraksi dari potongan sirip dengan menggunakan metode phenol-chloroform, sebagai berikut; 5-10 mg potongan sirip ikan dimasukkan ke dalam tabung 1,5 mL yang telah berisi $500 \mu \mathrm{L}$ larutan TNES urea. Kemudian ditambahkan $10 \mu \mathrm{g} / \mathrm{mL}$ Protein kinase dan diinkubasikan pada suhu $37^{\circ} \mathrm{C}$ selama 12 jam.

Sebanyak $500 \mu \mathrm{L}$ larutan phenol-chloroform ditambahkan ke dalam tabung di atas untuk selanjutnya divortex selama 1 menit dan disentrifuse pada kecepatan 10.000 rpm selama 10 menit. Lapisan supernatannya diambil dan dimasukkan ke dalam tabung baru, dan ditambahkan $600 \mu \mathrm{L}$ larutan propanol dan divortex sampai terlihat endapan putih.

DNA diendapkan dengan cara mensentrifus campuran tersebut pada kecepatan 10.000 rpm selama 10 menit, kemudian larutan diatasnya dibuang dan DNA dikeringkan pada suhu ruangan. Kemudian dilarutkan kembali dalam 50-100 $\mu \mathrm{L}$ Tris-EDTA (TE) buffer dan disimpan dalam $4^{\circ} \mathrm{C}$ sebelum digunakan pada tahap selanjutnya. Pemurnian hasil DNA dilakukan dengan metode dalam Lia (2006) yang telah mengalami modifikasi dalam beberapa hal.

\section{RAPD}

Penyeleksian terhadap 20 primer (OPA120) dilakukan untuk mendapatkan minimal 2 primer yang mempunyai produk amplifikasi yang sesuai dengan DNA ikan gurame.

Pengamplifikasian dilakukan menggunakan metode Polymerize Chain Reaction (PCR) dengan komposisi reaksi yang terdiri : $10 \mu \mathrm{g}$, 10 pmol setiap primer dan "pure taq DNA" 
(Promega) dengan total volume keseluruhannya $25 \mu \mathrm{L}$. Siklus PCR yang digunakan dalam amplifikasi adalah satu siklus denaturasi pada suhu $94^{\circ} \mathrm{C}$ selama 2 menit. 45 siklus penggandaan yang terdiri atas $94^{\circ} \mathrm{C}$ selama 1 menit, $36^{\circ} \mathrm{C}$ selama 1 menit dan $72^{\circ} \mathrm{C}$ selama 2,5 menit. Selanjutnya satu siklus terakhir pada suhu $72^{\circ} \mathrm{C}$ selama 10 menit.

Hasil amplifikasi kemudian dipisahkan secara elektroforesis dengan menggunakan gel agarose 2-3\% dalam Tris-Boric-EDTA (TBE) buffer dan diamati dengan illuminator (UV) serta dicetak gambarnya dengan polaroid.

\section{Analisis Data}

Untuk mengevaluasi variasi DNA antar ras ikan gurame dilakukan dengan menggunakan analisa molekuler varians (AMOVA) dan Fst dalam program TFPGA (Miller, 1997). Kekerabatan antar ras dianalisa dengan menggunakan Jarak Genetik, Nei (1972).

\section{HASIL DAN BAHASAN}

Dari 20 primer OPA yang diuji, hanya dua primer yaitu OPA-4 dan OPA-7 yang digunakan dalam analisis mengingat hasil amplifikasi yang lebih baik dibandingkan hasil amplifikasi dengan menggunakan primer OPA lainnya. Jumlah total pita yang diamati dari dua primer tersebut adalah 48 buah dengan panjang mulai 300 bp hingga 2.000 bp. Jumlah ini jauh lebih tinggi dibandingkan hasil amplifikasi pada galur murninya yang hanya teramati 28 buah (Nugroho, 2010). Menurut Falconer (1996) dan Tave (1993), perkawinan silang dapat meningkatkan keragaman, yang dalam hal ini ditunjukkan oleh jumlah lokus yang teramati.

Tingkat variasi heterozigositas dipengaruhi oleh jenis ras ikan gurame induk asal. Secara umum hasil persilangan ikan gurame yang diteliti mempunyai tingkat keragaman yang relatif tinggi dengan nilai heterozigositas rata-rata 0.163 , dengan nilai tertinggi terdapat pada persilangan antara Paris-Bastar (0.2721) kemudian diikuti oleh persilangan Bastar-Paris (0.1847), BlusafirBastar (0.1578), Paris-Blusafir (0.1355), BastarBlusafir (0.1163) dan Paris-Blusafir (0.1116) (Tabel 1). Nilai ini lebih rendah dari hasil yang diamati pada ikan Blusafir dari Priangan (Lia, 2006) dan galur murni Bastar, Paris, dan Blusafir (Nugroho, 2010). Fenomena ini semakin memperkuat hasil dari Nugroho (2010) yang mengindikasikan bahwa kemungkinan telah terjadi "akumulasi inbreeding" karena sebenarnya ras-ras yang ada adalah tidak berbeda nyata atau berasal dari populasi yang sama. Sehingga heterozigositas menjadi lebih rendah walaupun dengan makin bertambahnya jumlah lokus yang muncul pada saat perkawinan. Keadaan diatas menjadi lebih jelas jika dibandingkan heterozigositas antar persilangan dengan hasil "galur murninya". Rata-rata tingkat penurunan heterozigositas yang terjadi pada benih dibandingkan induknya berkisar antara $13,02 \%-47,45 \%$. Nilai ini setara dengan yang terjadi pada inbreeding ikan air tawar per generasinya.

Namun demikian heterosigositas ikan gurame yang diuji jauh lebih tinggi dibandingkan pada ikan air tawar lainnya. Umumnya, variasi genetik pada ikan air tawar tergolong cukup rendah sebagai akibat keterbatasan migrasi secara alami, seperti misalnya pada ikan kancra (Nugroho et al., 2006). Hal ini disebabkan komoditas gurame masih bersifat lokal dalam taraf pembudidayaannya (belum banyak dikembangkan secara luas) di mana peluang untuk genetic introgression dari populasi lain menjadi lebih

Tabel 1. Variasi genetik pada ikan gurame berdasarkan fragmen RAPD dengan primer OPA 4 dan 7

Table 1. Genetic variations of Giant gouramy based on the fragment of RAPD that was amplified with primers OPA 4 and 7

\begin{tabular}{lcccccc}
\hline & $\begin{array}{c}\text { Bastar- } \\
\text { Paris } \\
(A B)\end{array}$ & $\begin{array}{c}\text { Paris- } \\
\text { Bastar } \\
\text { (BA) }\end{array}$ & $\begin{array}{c}\text { Bastar- } \\
\text { Blusafir } \\
\text { (AC) }\end{array}$ & $\begin{array}{c}\text { Blusafir- } \\
\text { Bastar } \\
\text { (CA) }\end{array}$ & $\begin{array}{c}\text { Paris- } \\
\text { Blusafir } \\
\text { (BC) }\end{array}$ & $\begin{array}{c}\text { Blusafir- } \\
\text { Paris } \\
\text { (CB) }\end{array}$ \\
\hline Heterozigositas & 0.1874 & 0.2721 & 0.1163 & 0.1578 & 0.1355 & 0.1116 \\
Polymorphic loci (\%) & 46.43 & 64.28 & 25.00 & 39.28 & 32.14 & 25.00 \\
\hline
\end{tabular}


kecil yang berarti kecepatan menjadi satu populasi yang sama lebih lambat dibandingkan ikan air tawar lainnya. Relatif tingginya variasi genetik ini juga menunjukkan bahwa komoditas ini masih potensial dimanfaatkan sebagai ikan budidaya.

Lebih jauh, rendahnya tingkat keragaman pada hasil perkawinan yang salah satunya menggunakan induk betina dari ras Blusafir dan Paris memperkuat hasil dendrogram Nugroho (2010) yang menunjukkan bahwa Blusafir dan Paris mempunyai kekerabatan yang lebih dekat dibandingkan dengan ras Bastar. Di mana hasil perkawinan pada individuindividu dengan kekerabatan yang lebih dekat akan mempunyai tingkat keragaman yang lebih rendah dibandingkan dengan hasil perkawinan dari ras dengan kekerabatan yang jauh.
Keadaan ini akan terlihat lebih jelas pada hasil penghitungan jarak genetik berdasarkan fragmen dari dua primer. Jarak genetik yang dihitung menurut Nei (1972) tertera pada Tabel 2. Jarak genetik rata-rata antara hasil perkawinan antar ras ikan gurame adalah sekitar 0,119 . Nilai jarak genetik pada ikan gurame ini relatif lebih setara dibandingkan jarak genetik antara ikan gurame ras Bastar, Paris, dan Blusafir (Nugroho, 2010) dan ikanikan dari populasi yang yang sama, seperti pada ikan kancra (Nugroho et al., 2006).

Dendrogram yang dibentuk berdasarkan jarak genetik Nei (1972) menunjukkan bahwa hasil persilangan dengan menggunakan induk betina dari ras Bastar dikelompokkan dalam satu grup sedangkan grup lainnya terdiri atas hasil persilangan dengan menggunakan induk

Tabel 2. Jarak genetik Nei (1972)

Table 2. Nei's genetic distance (1972)

\begin{tabular}{|c|c|c|c|c|c|c|}
\hline & $\begin{array}{c}\text { Bastar- } \\
\text { Paris } \\
(A B)\end{array}$ & $\begin{array}{l}\text { Paris- } \\
\text { Bastar } \\
\text { (BA) }\end{array}$ & $\begin{array}{l}\text { Bast ar- } \\
\text { Blusafir } \\
\text { (AC) }\end{array}$ & $\begin{array}{l}\text { Blusafir- } \\
\text { Bast ar } \\
\text { (CA) }\end{array}$ & $\begin{array}{l}\text { Paris- } \\
\text { Blusafir } \\
\text { (BC) }\end{array}$ & $\begin{array}{c}\text { Blusafir- } \\
\text { Paris } \\
\text { (CB) }\end{array}$ \\
\hline$A B$ & & 0.0513 & 0.1733 & 0.1371 & 0.0743 & 0.2355 \\
\hline BA & & & 0.1301 & 0.0456 & 0.0760 & 0.1283 \\
\hline$A C$ & & & & 0.0931 & 0.1780 & 0.1867 \\
\hline CA & & & & & 0.0862 & 0.0916 \\
\hline$B C$ & & & & & & 0.1727 \\
\hline $\mathrm{CB}$ & & & & & & \\
\hline
\end{tabular}
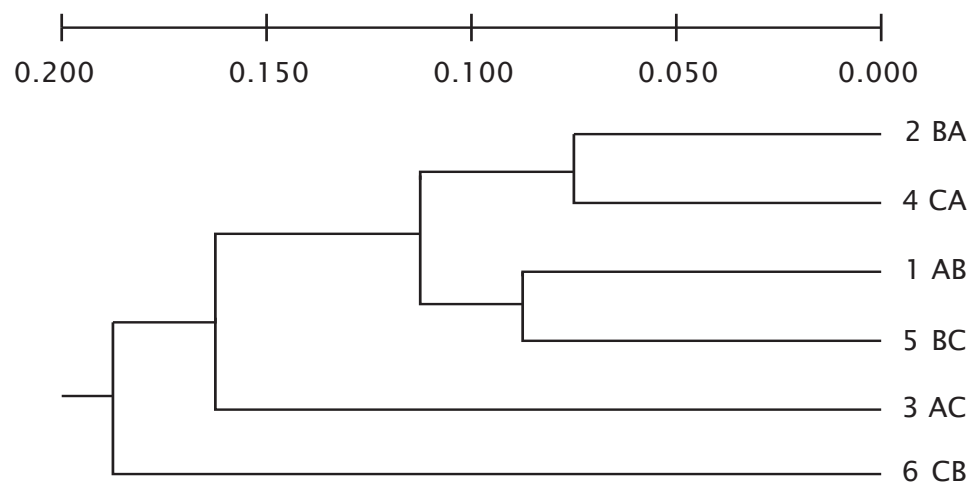

Gambar 1. Dendogram jarak genetik Nei (1972) dari persilangan antara ras berdasarkan RAPD menggunakan primer OPA4 dan OPA7

Figure 1. Dendrogram of Nei's genetic distance (1972) of hybrids of giant gouramy varieties based on RAPD markers with primer OPA 4 and OPA 7 
Tabel 3. Hasil uji Fst berpasangan

Table 3. Result of Fst comparison pairs test

\begin{tabular}{|c|c|c|c|c|c|c|}
\hline & $\begin{array}{c}\text { Bastar- } \\
\text { Paris } \\
(A B)\end{array}$ & $\begin{array}{l}\text { Paris- } \\
\text { Bastar } \\
\text { (BA) }\end{array}$ & $\begin{array}{l}\text { Bast ar- } \\
\text { Blusafir } \\
\quad(\mathrm{AC})\end{array}$ & $\begin{array}{l}\text { Blusafir- } \\
\text { Bastar } \\
\text { (CA) }\end{array}$ & $\begin{array}{l}\text { Paris- } \\
\text { Blusafir } \\
\text { (BC) }\end{array}$ & $\begin{array}{c}\text { Blusafir- } \\
\text { Paris } \\
\text { (CB) }\end{array}$ \\
\hline$A B$ & & $1^{\text {ns }}$ & $0.9350^{\mathrm{ns}}$ & $0.9200^{\mathrm{ns}}$ & $0.9983^{\text {ns }}$ & 0.2384 ns \\
\hline BA & & & 1 ns & 1 ns & 0.9995 ns & 0.9991 ns \\
\hline$A C$ & & & & 1 ns & 0.9899 ns & $0.9875 \mathrm{~ns}$ \\
\hline CA & & & & & $0.9988^{\mathrm{ns}}$ & $1^{\text {ns }}$ \\
\hline$B C$ & & & & & & 0.9806 ns \\
\hline $\mathrm{CB}$ & & & & & & \\
\hline
\end{tabular}

NS = Tidak berbeda nyata pada taraf alpha (Not significantly different on the significance level of $)>0,05$

betina dari ras Paris dan Blusafir. Hal ini menunjukkan bahwa ras Paris dan Blusafir mempunyai kekerabatan yang lebih dekat dibandingkan antara keduanya dengan ras Bastar, seperti hasil yang didapatkan oleh Nugroho (2010). Berdasarkan hasil pengamatan di lapangan, ikan gurame ras Paris dan Blusafir mempunyai corak yang serupa, dan yang membedakannya hanya dari warna sisiknya. Blusafir mempunyai warna lebih biru, sedangkan Paris dengan warna sisik lebih keabu-abuan.

Secara statistik dengan menggunakan AMOVA (Analysis Molecular Variance) menunjukkan bahwa tidak terdapat perbedaan yang nyata secara genetik pada benih yang dihasilkan antar pasangan ras ikan gurame yang diuji $(P>0,05)$ berdasarkan fragmen dari dua primer (Tabel 3). Hasil yang sama juga diperoleh dengan menggunakan metode isozyme terhadap ikan gurame ras Bastar, Bule, dan Blusafir (Nugroho \& Kusmini, 2007; dan Nugroho, 2010) yang mendapatkan ikan gurame ras Bastar, Paris, dan Blusafir juga tidak berbeda nyata. Hal ini menunjukkan bahwa kemungkinan ketiga ras tersebut berasal dari nenek moyang populasi yang sama. Perbedaan yang ada secara fenotif yaitu berupa warna dan ukuran sisik kemungkinan adalah pengaruh lingkungan. Namun demikian fenomena ini masih memerlukan kajian lebih lanjut.

\section{KESIMPULAN}

Tidak terdapat perbedaan yang nyata secara genetik antara hasil persilangan antar ikan gurame ras Bastar, Paris, dan Blusafir. Keragaman tertinggi dimiliki ikan gurame hasil persilangan Paris-Bastar (heterozygositas= 0,2721 ), diikuti hasil persilangan Bastar-Paris $(0,1847)$, Blusafir-Bastar $(0,1578)$, Paris-Blusafir $(0,1355)$, Bastar-Blusafir $(0,1163)$, dan ParisBlusafir $(0,1116)$.

\section{UCAPAN TERIMA KASIH}

Penulis mengucapkan terima kasih kepada Badan Penelitian dan Pengembangan Kelautan dan Perikanan serta Balai Riset Perikanan Budidaya Air Tawar, Bogor atas terlaksananya kegiatan ini dan dukungan dana melalui program riset-DIPA tahun 2010.

\section{DAFTAR ACUAN}

Falconer, D.S. 1996. Introduction to quantitative genetics. Longman Malaysia, p. 281 288.

Kusmini, I.I., Hadie, L.E., Hadie, W., \& Kristanto, A.H. 2000. Karakterisasi dalam karakter fenotip beberapa ras ikan gurame (Osphronemus gouramy) yang berpotensi dalam budidaya dengan analisis truss morfometrik. Prosiding Simposium Nasional Pengelolaan Plasma Nutfah. Bogor, hlm. 614-620.

Miller, P.M. 1999. Tools for Population Genetic Analysis (TFPGA). Software, 30 pp.

Lia, Emah. 2006. Analisa keanekaragaman genetic ikan gurame (Osphronemus gouramy Lac) varietas Blusafir dengan menggunakan metode RAPD. Skripsi S1, Jurusan Pendidikan Biologi. Universitas 
Pendidikan Indonesia (UPI) Bandung, 95 hlm.

Nugroho, E., Satyani, D., \& Kalimah, S., \& Rusmaedi. 1993. Evaluasi potensi genetic dari beberapa ras gurame. Bulletin Penelitian Perikanan Darat, 12(1): 30-36.

Nugroho, E., Subagja, J., Asih, S., \& Kurniasih, T. 2006. Evaluasi keragaman genetik ikan kancra dengan menggunakan marker mtDNA D-loop dan Random Amplified Polymorphism DNA (RAPD). Jurnal Riset Akuakultur, 1, 2:211-217.

Nugroho, E. \& Kusmini, I.I. 2007. Evaluasi variasi genetik tiga ras ikan gurame (Osphronemus gouramy) dengan metodee isozyme. Jurnal Riset Akuakultur, 2: 51-57.

Nugroho, E. 2010. Evaluasi genetik ras-ras ikan gurame dengan menggunakan marker DNA (unpublish).

Nei, M. 1972. Genetics distance between populations. American Nature, 106: 283-292.

Setijaningsih, L., Arifin, O.Z., \& Gustiano, R. 2007. Karakterisasi tiga strain ikan gurame (Osphronemus gouramy) berdasarkan metode truss morfometrik. Jurnal Iktiologi Indonesia, 7(1): 23-30.

Soewardi, K. 1995. Karakterisasi populasi ikan gurame Osphronemus gouramy lac dengan metode biokimia. Jurnal IImu-IImu Perairan dan Perikanan Indonesia, 3(2): 23-31.

Soewardi, K., Rachmawati, R., Affandi, R., \& Bengen, D.G. 1995. Penelusuran varietas ikan gurame Osphronemus gouramy Lac berdasarkan penampilan karakter luar. Jurnal IImu-IImu Perairan dan Perikanan Indonesia, 3(2): 31.

Sudarto. 1989. Porselin, Blue Safir dan Paris yang bertelur. Warta Penelitian dan Pengembangan Pertanian, 11 (2): 1-2.

Suseno, D., Rusmaedi, Iriana, I., Dharma, L., \& Arifin, O.Z. 2000. Karakterisasi morfologi ikan gurame strain Soang dan Paris. Simposium Nasional Pengelolaan Pemuliaan dan Plasma Nutfah, hlm. 589-595.

Tave, D. 1993. Genetics for fish hatchery managers. The AVI Publ. Comp. Inc. NY. USA, $254 \mathrm{pp}$. 